\title{
SOSIALISASI PERAN ORANG TUA DI MASA PANDEMIK COVID 19 DALAM PEMBELAJARAN DARING BAGI ANAK USIA SEKOLAH DASAR DESA CIKALONGSARI KARAWANG
}

\author{
Yayan Alpian $^{1}$, Sri Wulan Anggraeni ${ }^{2}$, Vickry Rizky Faddillah ${ }^{3}$ \\ Pendidikan Guru Sekolah Dasar \\ Fakultas Keguruan dan Ilmu Pendidikan \\ Universitas Buana Perjuangan Karawang \\ yayan.alpian@ubpkarawang.ac.id \\ wulan.anggraeni@ubpkarawang.ac.id \\ vickyfaddillah@gmail.com
}

\begin{abstract}
Abstrak
Kegiatan pengabdian kepada masyarakat ini bertujuan untuk mengetahui peran apa saja yang orang tua berikan selama mendampingi anak dalam kegiatan belajar di rumah pada anak usia Sekolah Dasar di masa pandemi Covid-19. Metode yang digunakan dalam kegiatan pegabdian kepada masyarakat ini melalui kegiatan yang dikemas secara workshop tentang peran orang tua di masa pandemic Covid-19 dalam pembelajaran daring bagi anak usia sekolah dasar, sedangakan yang menjadi khalayak sasarannya adalah para orang tua di Desa Cikalongsari Kecamatan Jatisari Kabupaten Karawang. Hasil kegiatan pengabdian kepada masyarakat ini memberikan pengetahuan dan pemahaman bagi orang tua dalam membantu, membimbing anak belajar secara daring di rumah dan memahami bagaimana pentingnya pengawasan bagi anak dalam proses pendidikan, sekaligus dapat merasakan bagitu berat tugas seorang guru dalam mendidik anak di sekolah.
\end{abstract}

Kata Kunci: peran orang tua, masa pandemi covid-19

\begin{abstract}
This community service activity aims to find out what roles parents give while accompanying children in learning activities at home for elementary school aged children during the Covid19 pandemic. The method used in community service activities is through activities that are packaged in workshops on the role of parents during the Covid-19 pandemic in online learning for elementary school aged children, while the target audience is parents in Cikalongsari Village, Jatisari District, Karawang Regency. The results of this community service activity provide knowledge and understanding for parents in helping, guiding children to learn online at home and understanding how important supervision is for children in the educational process, as well as being able to feel how heavy a teacher's task is in educating children at school.
\end{abstract}

Keywords: the role of parents, during the Covid-19 pandemic 


\section{PENDAHULUAN}

Saat ini seluruh dunia sedang mengalami kondisi yang sangat mengkhawatirkan dengan munculnya bencana wabah penyakit yang menyerang manusia. Wabah penyakit ini muncul pertama kali pada akhir tahun 2019 di negara China tepatnya di kota Wuhan yang terkenal dengan sebutan Virus Corona atau severe acute respiratory syndrome coronavirus 2 (SARS-CoV-2) yang menyerang sistem pernapasan. Penyakit karena infeksi virus ini disebut COVID-

19. Virus Corona bisa menyebabkan gangguan ringan pada sistem pernapasan, infeksi paruparu yang berat, hingga kematian. Di Indonesia sendiri masuknya virus corona pada awal tahun 2020 dengan ditemukannya dua orang pasien asal kota Depok yang terpapar virus ini, dengan ditemukannya kasus ini sehingga pemerintah bergerak cepat agar virus corona ini tidak dengan cepat menyebar dan menular semakin luas kepada masyarakat dengan salah satunya mengeluarkan kebijakan melalui Keputusan Presiden Republik Indonesia Nomor 11 Tahun 2020 Tentang Penetapan Kedaruratan Kesehatan Masyarakat Corona Virus Disease (Covid19), dan diperkuat oleh Keputusan Presiden Nomor 9 Tahun 2020 tentang Tentang Perubahan Atas Keputusan Presiden Nomor 7 Tahun 2020 Tentang Gugus Tugas Percepatan Penanganan Corona Virus Disease 2019 (Covid-19), selain itu juga dikeluarkannya Peraturan Pemerintah Republik Indonesia Nomor 21 Tahun 2020 tentang Pembatasan Sosial Berskala Besar Dalam Rangka Percepatan Penanganan Covid-19 sehingga segala aktivitas dibatasi tak terkucuali di dunia pendidikan itu sendiri dengan menggunakan mengeluarkan kebijakan untuk sekolah melaksanakan proses belajar mengajar siswa dan guru di rumah.

Menteri Pendidikan Nadiem Anwar Makarim menerbitkan Surat Edaran Nomor 36962/MPK.A/HK/2020 tentang Pembelajaran secara Daring dan Bekerja dari Rumah dalam Rangka Pencegahan Penyebaran Corona Virus Disease (COVID- 19), dan diperkuat Surat Edaran Menteri Pendidikan dan Kebudayaan Republik Indonesia Nomor 4 Tahun 2020 tentang Pelaksanaan Pendidikan dalam Masa Darurat Coronavirus Disease Covid-19 maka kegaiatan belajar dilakukan secara daring dalam rangka pencegahan penyebaran coronavirus disease Covid19. Hal ini diperkuat oleh Surat Edaran Gubernur Jawa Barat tentang peningkatan kewaspadaan terhadap resiko penularan infeksi coronavirus disease-19 (COVID-19). Kebijakan ini memaksa guru dan siswa untuk tetap bekerja dan belajar dari rumah dari jenjang PAUD sampai Perguruan Tinggi. Kebijakan ini tentunya tidak hanya berdampak pada relasi guru dan siswa namun juga pentingnya peran orang tua dalam memberikan pendidikan dan dan pelaksanaan kegiatan belajar dari rumah atau pembelajaran daring terhadap anak.

Tujuan pembelajaran daring ini adalah memastikan pemenuhan hak peserta didik untuk mendapatkan layanan pendidikan selama darurat Covid-19, melindungi warga satuan 
pendidikan dari dampak buruk Covid-19, mencegah penyebaran dan penularan Covid-19 di satuan pendidikan dan memastikan pemenuhan dukungan psikososial bagi pendidik, peserta didik, dan orang tua. Selain itu, peran orang tua dalam memberikan bimbingan pendidikan serta pembelajaran yang baik selama kegiatan belajar dari rumah ini, orang tua juga memiliki peran mengajarkan agar bagaimana hidup sehat di tengah masa pandemi Covid-19 ini.

Kegiatan belajar dari rumah atau pembelajaran daring yang dilakukan anak-anak selama pandemi berlangsung memunculkan beragam kondisi diantaranya adalah jenuh dan menurunnya semangat anak-anak dalam belajar. Seperti yang disebutkan dalam penelitian Mastura dan Rustan Santaria (2020) bahwa dampak dari situasi pandemi Covid-19 pada peserta didik adalah kurangnya dalam mempersiapkan diri, seperti motivasi peserta didik yang kurang dalam mengikuti pembelajaran daring. Peserta didik yang biasanya mengikuti pembelajaran di kelas dengan teman-teman harus dihadapkan dengan belajar di rumah sendiri sehingga peserta didik merasa jenuh. Kemudian libur panjang yang terlalu lama membuat peserta didik bosan dan jenuh, membuat mereka ingin keluar rumah. Senada dengan hasil penelitian Khasanah (2020) yang mengatakan bahwa pada awalnya banyak orang tua yang menolak pembelajaran daring untuk anaknya, karena mereka masih awam terhadap teknologi. Dalam hal ini, peran orang tua pada pembelajaran daring yang dilaksanakan oleh anak dirumah adalah membimbing dan memberikan motivasi kepada anak, agar anak tetap bersemangat dalam melakukan kegiatan di rumah.

Peran orang tua dalam mendampingi kesuksessan pada pendidikan anak terutama di Sekolah Dasar Desa Cikalongsari selama belajar di rumah merupakan hal yang sangat di pentingkan karena pada masa pandemi Covid-19 ini anak lebih cenderung memiliki banyak waktu belajar di rumah. Menurut Lestari (2012: 153) menyatakan bahwa peran orang tua merupakan cara yang digunakan oleh orang tua berkaitan dengan pandangan mengenai tugas yang harus dijalankan dalam mengasuh anak. Berkaitan dengan hal tersebut WHO, (2020) merilis berbagai panduan bagi orang tua dalam mendampingi putra-putri mereka selama pandemi ini berlangsung yang meliputi tips pengasuhan agar lebih positif dalam mendampingi anak selama berkreativitas di rumah.

Menurut Nurlaeni dan Juniarti (2017) mengatakan bahwa orang tua pada awalnya berperan dalam membimbing sikap serta keterampilan yang mendasar, seperti pendidikan agama untuk patuh terhadap aturan, dan untuk pembiasaan yang baik. Namun peran orang tua menjadi lebih meluas yaitu sebagai pendamping pendidikan akademik. Zahrok dan Suarmini (2018) menyatakan bahwa keluarga menjadi satu bagian yang paling penting dalam menjadikan anak lebih baik salah satunya adalah dengan pendidikan. Pendidikan yang 
dimaskud yang diberikan oleh orang tua dilingkungan keluarga yaitu diajarkan tentang keberadaan Tuhan yang maha Esa dan diajarkan cara beribadah yang benar sesuai keyakinan dan kepercayaan, menanamkan nilai dan norma yang baik sesuai dengan tingkah laku, rasa cinta dan kasih sayang, rasa aman, serta perhatian diantara anggota keluarga.

Setiap Guru dan orang tua sama-sama memiliki komitmen untuk kesuksesan belajar anak di tengah pandemi corona virus, keterlibatan orang tua dalam membina kerja sama dengan guru yaitu harus mendukung dan menjalankan komitmen yang sudah dibuat oleh guru dengan orang tua dalam membentuk karakter kedisiplinan anak sedangkan untuk pendukung pelaksanaannya orang tua yang tetap berada di rumah, akses internet yang mendukung, memiliki komunikasi yang baik antara orang tua dengan guru, latar belakang pendidikan orang tua, dan memiliki komitmen untuk melaksanakan pembelajaran jarak jauh. Adapun permasalahan yang dihadapi oleh orang tua terutama di Desa Cikalongsari pada masa pandemi Covid-19 yakni, kurangnya komunikasi orang tua dengan guru, dan kurangnya pengetahuan orang tua menggunakan aplikasi untuk belajar daring.

Mengacu pada permasalahan yang diajukan untuk dipecahkan, maka tujuan kegiatan ini adalah:

1. Memberikan penyuluhan dan sosialisasi peran orang tua di masa pandemik covid 19 dalam pembelajaran daring bagi anak usia sekolah dasar yang diberikan kepada warga masyarakat Desa Cikalongsari Kecamatan Jatisari Kabupaten Karawang.

2. Memberikan pengetahuan dan pemahaman mengenai peran orang tua di masa pandemik covid 19 dalam pembelajaran daring bagi anak usia sekolah dasar yang diberikan kepada warga masyarakat Desa Cikalongsari Kecamatan Jatisari Kabupaten Karawang.

\section{METODE}

Permasalahan yang ada di warga masyarakat Desa Cikalongsari Kecamatan Jatisari Kabupaten Karawang masih kurang memahami pentingnya komunikasi orang tua dengan guru, kurangnya pemahaman peran orang tua dalam proses pembelajaran anak di rumah pada masa pandemic covid 19 ini, dan kurangnya pengetahuan orang tua menggunakan aplikasi untuk belajar daring diselesaikan menggunakan metode ceramah dengan teknik presentasi materi tentang peran orang tua di masa pandemik covid 19 dalam pembelajaran daring bagi anak usia sekolah dasar yang dilanjutkan dengan diskusi. Kegiatan ini dikemas dalam bentuk workshop.

\section{A. Langkah-langkah kegiatan}

Berikut ini adalah langkah-langkah pelatihan yang dilakukan: 


\section{Tahap Persiapan}

Tahap persiapan yang dilakukan meliputi:

a) Survey

Sebelum melaksanakan kegiatan pengabdian masyarakat terlebih dahulu dilakukan survey lokasi kegiatan yang berada di Desa Cikalongsari Kecamatan Jatisari Kabupaten Karawang. Survey dimaksudkan untuk melihat situasi kebutuhan terkait pengabdian masyarakat dan sejauh mana tingkat kebutuhan yang diperlukan oleh peserta kegiatan pengabdian masyarakat tersebut.

b) Pemantapan dan penetuan lokasi dan sasaran

Penyusunan bahan/materi penyuluhan dan sosialisasi, yang meliputi: materi dengan media power point bagi warga masyarakat Desa Cikalongsari Kecamatan Jatisari Kabupaten Karawang.

\section{Tahap Pelaksanaan Kegiatan}

Tahap pelaksanaan kegiatan dilakukan persiapan. Dalam tahap ini dilakukan pertama, penjelasan materi terkait tentang peran orang tua di masa pandemik covid 19 dalam pembelajaran daring bagi anak usia sekolah dasar, sesi penyuluhan dan sosialisasi ini menitikberatkan pada pemberian pengetahuan, penjelasan serta memotivasi para orang tua agar lebih berperan aktif dalam pemdampingan bagi anak dalam proses belajar di rumah pada masa pandemic covid 19.

3. Metode Pelatihan

Untuk melaksanakan kegiatan tersebut digunakan beberapa metode pelatihan, yaitu:

\section{a. Metode Ceramah}

Metode ceramah dipilih untuk memberikan pengetahuan dan penjelasan tentang materi peran orang tua di masa pandemik covid 19 dalam pembelajaran daring bagi anak usia sekolah dasar: memberikan pemahaman kepada orang tua mengenai pentingnya peran orang tua, pentingnya pendidikan bagi anak dan masa pandemic covid 19. b. Metode Tanya Jawab

Metode tanya jawab sangat penting bagi para peserta kegiatan, baik di saat menerima pengetahuan dan penjelasan materi mengenai orang tua mengenai pentingnya peran orang tua, pentingnya pendidikan bagi anak dan masa pandemic covid 19. Metode ini memungkinkan para orang tua menggali pengetahuan sebanyak-banyaknya tentang pentingnya peran orang tua dalam pendampingan proses belajar anak di masa pandemik covid 19. 


\section{HASIL DAN PEMBAHASAN}

Program pengabdian kepada masyarakat dilaksanakan dengan melibatkan mahasiswa untuk menjadi salah satu narasumber dalam kegiatan yang dikemas secara workshop. Pelibatan mahasiswa dimaksudkan untuk menumbuhkembangkan kompetensi mahasiswa dalam hal berinteraksi dan mengembangkan kemampuannya dalam penyampaian materi di depan umum secara akademis tentang bagaimana peran orang tua dalam pendampingan belajar anak di masa covid 19, sekaligus memberikan kesempatan kepada mahasiswa untuk dapat mengaplikasikan pendekatan konseling dalam proses pemberdayaan masyarakat melalui sistem keluarga yang berbasis pendidikan.

Kegiatan penyuluhan dan sosialisasi yang dikemas secara workshop ini diharapkan dapat memotivasi dan menumbuhkan kesadaran bagi orang tua di Desa Cikalongsari Kecamatan Jatisari Kabupaten Karawang akan pentingnya peran orang tua dalam membantu, membimbing anak belajar di masa covid 19. Sejalan dengan hasil penelitian Euis Kurniati, dkk (2020) mengatakan bahwa secara umum peran orang tua yang muncul selama pandemi covid19 adalah sebagai pembimbing, pendidik, penjaga, pengembang dan pengawas dan secara spesifik menunjukkan bahwa peran orang tua adalah menjaga dan memastikan anak untuk menerapkan hidup bersih dan sehat, mendampingi anak dalam mengerjakan tugas sekolah, melakukan kegiatan bersama selama di rumah, menciptakan lingkungan yang nyaman untuk anak, menjalin komunikasi yang intens dengan anak, bermain bersama anak, menjadi role model bagi anak, memberikan pengawasan pada anggota keluarga, menafkahi dan memenuhi kebutuhan keluarga, dan membimbing dan memotivasi anak, memberikan edukasi, memelihara nilai keagamaan, melakukan variasi dan inovasi kegiatan di rumah.

Setelah mengikuti kegiatan ini, diharapkan memperolehan solusi untuk mengatasi berbagai masalah yang dihadapi oleh orang tua terutama di Desa Cikalongsari terkait proses pendampingan belajar anak di rumah dengan metode jarak jauh atau daring, salah satu solusi yang dapat diberikan yaitu pihak sekolah agar mengadakan pengarahan terlebih dahulu terhadap orang tua dengan tetap mengikuti protokol kesehatan yang dianjurkan oleh pemerintah. Pengarahan bisa berupa menjelaskan bagaimana penggunaan google classroom atau aplikasi belajar daring lainnya. Guru juga dapat membuat grup bersama orang tua di dalam sebuah aplikasi untuk mendekatkan komunikasi guru dengan orang tua. Di dalam grup tersebut Guru juga dapat menjelaskan bagaimana memberikan materi pembelajaran yang akan disampaikan terhadap anak-anak, agar orang tua pun tidak merasa kebingungan atapun keliru dalam menyampaikan atau memberikan penjelasan materi pembelajaran serta agar orang tua tidak merasa kesulitan mengajarkan pembelajaran jarak jauh atau daring terhadap anak. 


\section{KESIMPULAN DAN SARAN}

Peran orang tua dalam mendampingi kesuksessan pada pendidikan anak terutama pendidikan anak usia Sekolah Dasar Desa Cikalongsari selama belajar di rumah menjadi sangat di pentingkan karena pada masa pandemi Covid-19 ini anak lebih cenderung memiliki banyak waktu belajar di rumah. Selain itu komunikasi yang terjalin antara orang tua dan guru sangat di pentingkan pada masa pandemik seperti ini karena guru dan orang tua merupakan kunci dari kesuksesan pembelajaran jarak jauh atau pembelajaran daring. Guru dan orang tua merupakan pendidik yang diharapkan mampu bekerjasama dalam kesuksesan belajar jarak jauh di tengah pandemi covid 19. Tanpa adanya komunikasi yang dilakukan oleh orang tua dan guru, tentu proses pendidikan yang di harapkan tidak akan terwujud. Adapun bentuk komunikasi guru dengan orang tua yang dilaksanakan di Desa Cikalongsari ini meliputi Kerjasama yang dilakukan dengan menggunakan sebuah aplikasi.

\section{DAFTAR PUSTAKA}

Keputusan Presiden Republik Indonesia Nomor 9 Tahun 2020 tentang Tentang Perubahan Atas Keputusan Presiden Nomor 7 Tahun 2020 Tentang Gugus Tugas Percepatan Penanganan Corona Virus Disease 2019 (Covid-19).

Keputusan Presiden Republik Indonesia Nomor 11 Tahun 2020 Tentang Penetapan Kedaruratan Kesehatan Masyarakat Corona Virus Disease (Covid- 19).

Khasanah, D. R. A. U., Hascaryo Pramudibyanto, Barokah Widuroyekti. (2020). Pendidikan Dalam Masa Pandemi Covid-19. Jurnal Sinestesia. 10 (01), 41-48.

Kurniati, E., Dina Kusumanita Nur Alfaeni., Fitri Andriani. (2020). Analisis Peran Orang Tua dalam Mendampingi Anak di Masa Pandemi Covid-19. Jurnal Obsesi: Jurnal Pendidikan Anak Usia Dini. 5 (1), 241-256.

Lestari, S. (2012) Psikologi Keluarga. Jakarta: Kencana Prenada Media Group.

Mastura dan Rustan Santaria. (2020) Dampak Pandemi Covid-19 terhadap Proses Pengajaran bagi Guru dan Siswa. Jurnal Studi Guru dan Pembelajaran. 3 (2), 285-295

Nurlaeni, N., dan Yenti Juniarti. (2017). Peran Orang Tua Dalam Mengembangkan Kemampuan Bahasa Pada Usia 4 Sampai 6 Tahun. Jurnal Pelita PAUD. 2 (1), 51-62.

Peraturan Pemerintah Republik Indonesia Nomor 21 Tahun 2020 tentang Pembatasan Sosial Berskala Besar Dalam Rangka Percepatan Penanganan Covid-19.

Surat Edaran Menteri Pendidikan dan Kebudayaan Republik Indonesia Nomor 4 Tahun 2020 tentang Pelaksanaan Pendidikan dalam Masa Darurat Coronavirus Disease Covid-19.

Surat Edaran Menteri Pendidikan dan Kebudayaan Republik Indonesia Nomor 36962/MPK.A/HK/2020 Tahun 2020 tentang Pembelajaran secara Daring dan Bekerja 
dari Rumah dalam Rangka Pencegahan Penyebaran Corona Virus Disease (COVID19).

WHO. (2020). Coronavirus disease (COVID-19) advice for the public: Advocacy. www.Who.Int.https://www.who.int/emergencies/diseases/novel-coronavirus2019/advice-forpublic/healthy-parenting

Zahrok, S., dan Ni Wayan Suarmini. (2018). Peran Perempuan Dalam Keluarga. Prosiding SEMATEKSOS 3"Strategi Pembangunan Nasional Menghadapi Revolusi Industri 4.0" Iptek Journal of Processing Series. 5 (3), 61-65. 